\title{
Türk Dünyasından Gelen Öğrencilerin Türkiye Türkçesi Metinlerine Yönelik Tutumlan ${ }^{*}$
}

\author{
Fahri Temizyürek $^{* *}$ \\ Muhammed Eyyüp Sallabaş ${ }^{* * *}$
}

\begin{abstract}
$0 ̈ z$
Türk dünyasından gelen ve “Türk soylular” olarak adlandırılan öğrenciler Türkiye'ye iş, eğitim, evlilik gibi sebeplerle gelerek Türkiye Türkçesi öğrenmektedirler. Türkçenin öğretiminde ise metinler, gerek ders kitaplarında gerekse okuma kitaplarında öğretimin temel unsuru olarak kullanılmaktadır. Bu bakımdan Türk dünyasından gelen öğrencilerin, Türk dünyasının tarihî süreç içerisinde ortaya koyduğu müşterek edebî ürünler vasıtasıyla dil öğrendiklerinde Türkiye Türkçesine karşı olumlu ilgi ve tutum geliştirmeleri beklenmektedir. Bir nesne veya duruma karşı tepki verme eğilimi olarak adlandırılan tutum, eğitim-öğretimin de en önemli unsurlarından biridir. Öğrendikleri dile veya o dilin bir becerisi olarak okumaya karşı olumlu tutum geliştiren öğrencilerin dil öğrenmedeki başarılarının bu tutumlarından etkilenmesi beklenir. Karma yöntemden yararlanılan bu çalışmada, Türk dünyasından gelen öğrencilerin Türkçe metinlere yönelik tutumları araştırılmıştır. Araştırma sonucunda öğrencilerin, Türkçe metinlere yönelik yüksek düzeyde tutum geliştirdikleri ve Türk dünyasının ortak kültürel unsurlarını okuma metinlerinde görmeyi bekledikleri belirlenmiştir.
\end{abstract}

\section{Anahtar Kelimeler}

Türk dünyası, Türkiye Türkçesi, Türk soylular, Türkçe öğretimi, tutum, Okuma tutumu.

\footnotetext{
Geliş Tarihi: 05 Mart 2019 - Kabul Tarihi: 17 Nisan 2019

Bu makaleyi şu şekilde kaynak gösterebilirsiniz:

Temizyürek, Fahri ve Muhammed Eyyüp Sallabaş (2020). “Türk Dünyasından Gelen Öğrencilerin Türkiye Türkçesi Metinlerine Yönelik Tutumları”. bilig - Türk Dünyası Sosyal Bilimler Dergisi 95: 1-26.

** Prof. Dr., Gazi Üniversitesi, Eğitim Fakültesi, Türkçe Eğitimi Bölümü - Ankara/Türkiye ORCID ID: 0000-0002-0497-1045

fahri@gazi.edu.tr

${ }^{* * *}$ Prof. Dr., Yıldız Teknik Üniversitesi, Eğitim Fakültesi, Sosyal Bilimler ve Türkçe Eğitim Bölümü İstanbul/Türkiye ORCID ID: 0000-0003-4346-4385

sallabas@yildiz.edu.tr
} 


\section{Giriş}

Tutum, bireyin çevresindeki herhangi bir olgu veya nesneye karşı sahip olduğu tepki eğilimidir. Kağıtçıbaşı̀ya (1983) göre tutum, doğrudan gözlenebilen bir özellik değildir ancak bireyde gözlenebilen davranışlara yol açarlar. Tutumların duygu, düşünce ve davranış olmak üzere üç öğesi vardır. Çevre ile ilgili, duyum ve deneyimlerin sınıflandırılmasının yanı sıra bu sinıflandırmaların olumlu, olumsuz olaylarla, arzulanan ya da arzulanmayan amaçlarla ilişkilendirilmesi söz konusudur. Böyle bir ilişkinin varlığı, tutumun duygusal öğesini temsil eder. Zihinsel öğe bireyin düşünme süreçlerinde kullandığı bir sınıflama, yani bilgilerin gruplandırılması olgusudur. $\mathrm{Bu}$ gruplamalar, bireyin birbirinden net bir şekilde uyarılara karşı tepkilerinde gösterdikleri farklılıkları ifade eder. Davranışsal öğe, bireyin belli bir uyarıcı grubundaki tutum konusuna karşı davranış eğilimini yansıtır. Bu davranış eğilimleri sözler ya da diğer hareketlerden gözlenebilir (İnceoğlu 2000).

Tutumların davranışlar üzerindeki belirleyici etkisinin olması eğitim sürecinde tutumların değiştirilmesi için uygun eğitim ortamlarının hazırlanmasını gündeme getirmiştir. Bu değişiklik sürecinin en önemli basamaklarından biri tutumların ölçülmesidir (Ünal ve İşeri 2012: 1076). Araştırmaya tabi tutulan yönleri doğrultusunda belirlenen tutumlar, olumlu veya olumsuz yönde olmalarına bağlı olarak eğitimin konusu hâline gelirler. Tutumlar, öğrenciler açısından düşünüldüğünde okula, öğretmene, herhangi bir derse veya okuma-yazma gibi pek çok becerinin kazanılmasına ve kullanılmasına yönelik olumlu veya olumsuz olarak gelişebilmektedir (Baştuğ ve Keskin 2013).

Tutumların doğrudan dil becerilerini ve bu becerilerden biri olan okumayı da doğrudan etkilediği söylenebilir. Okuma tutumu, okuyucunun kendini olumlu algılaması şeklinde ortaya çıkan içsel motivasyon fikri, istek, okumaya eğilimli olmak, okuma ilgisi veya aksine okuyucu olarak kendini olumsuz algılama, okumadan kaçınma isteği ya da bu etkinlikten hoşlanmamak olarak tanımlanabilir (Sainsbury ve Clarkson 2008: 2-3). Öğrenmelerin çoğunlukla metinler aracilı̆̆gyla gerçekleştiği göz önünde tutulduğunda okumaya yönelik tutumlar da önem kazanmaktadır.

Okumaya yönelik olumlu tutum geliştiren öğrenciler okuduğunu anlamada daha başarılıdırlar (Sallabaş 2008). Bu yüzden öğrencilere sadece okumanın öğretildiği ancak okumaya yönelik olumlu tutumlarının geliştirilmediği bir 
eğitim-öğretim sürecinden beklenen fayda elde edilemez. Okumayı zevkli hâle getirmek, bireysel ilgileri artırmak ve okumaya yönelik olumlu tutum geliştirmek, okuma alışkanlığı kazandırmada etkilidir (Karasu 2013). Buna göre, Türkçenin ikinci dil olarak öğretiminde kullanılan metinleri okuyan öğrencilerin okuma tutumları yüksek olduğunda Türkçe metinleri anlamada daha başarılı olacakları, dolayısıyla Türkçe öğrenirken daha istekli olacakları söylenebilir. Zira yapılan araştırmalar tutumların ikinci dili öğrenmede de etkili olduğunu göstermektedir.

İkinci dil eğitiminde önemli bir unsur olan tutum, öğrencinin hedef dili kolay veya zor öğrenmesinde önemli bir etmendir ama bu etmen eğitim sırasında herhangi bir sorun çıkmadıkça genellikle göz ardı edilmektedir. Oysaki dil eğitiminde öğrencilerin başarısı sadece onların öğrenme gücü ile alakalı değildir, aynı zamanda öğrencilerin dil eğitimine yönelik tutumları ile yakından ilişkilidir. Bu sebeple yabancı dil eğitiminde öğrencilerin öğrenecekleri dile karşı tutumlarının belirlenmesi, güdülenmeleri için alınacak önlemlerde çok önemlidir. İkinci dil öğrenen kişinin olumlu tutumları içsel öğrenme isteğini arttırarak dil öğrenme sürecini kolaylaştırır (Karatay ve Kartallıoğlu 2016). Tutumların başarının yordanmasında bir araç olduğu düşünülürse, öğrendiği dile karşı olumlu tutum geliştiren öğrencilerin başarılı olacağı, olumsuz tutum geliştiren öğrencilerin ise başarısız olacakları söylenebilir.

Türkçenin ikinci dil olarak eğitimi birbirini etkileyen ve tamamlayan pek çok unsurun birlikte işe koşulmasıyla gerçekleştirilmektedir. Bu bakımdan Türkiye Türkçesinin gerek yabancı dil olarak gerekse Türk soylulara öğretimi sadece ders kitaplarının hazırlanması ve sınıf içi etkinliklerinin düzenlenmesinden ibaret değildir. Öğrenciler sınıf ortamından ayrıldıktan sonra Türkçenin konuşulduğu dış dünyada da Türkçe metinlerle karşlaşmaktadırlar. Okuma becerisi sadece sınıf ortamında değil günlük hayatta da öğrencilerin karşııına çıkmaktadır. Okuma etkinliğini sadece ders kitapları olarak görmek isteyen bir öğrenci bilgi ve becerilerini sadece kitaptaki bilgi ve becerilerle sınırlayabilecektir. Akademik gelişme için öğrencilerin farklı alanlarla ilgili olarak Türkçe metinler okuması gerekmektedir. Bunun yapılabilmesi için de öğrencilerin Türkçe metin okumaya karşı olumlu bir tutum geliştirmesi öğrencilerin okuma ve buna bağlı dil becerilerinin geliştirilmesine katkı sağlayabilecektir (Sallabaş vd. 2018). 
Özellikle Türk dünyası ortak metinlerinin Türk dünyasından gelen öğrencilerinin Türkçe öğrenmelerinde kaynak metin olarak kullanılması, öğrencilerin Türkiye Türkçesine karşı ilgi ve tutumlarının artmasında önemli rol oynayacaktır. Bu noktada, Türk soylu öğrencilere Türkiye Türkçesi öğretiminde kullanılabilecek öncelikli metinler halk edebiyatına ait türlerdir. Türkiye'de, Türk dünyası halk bilgisi ürünleri hakkında yapılan çalışmalarla ortak Türk geçmişinin, ortak bir Türk geleceğine dönüşmesi konusunda çok ciddi mesafe kat edilmiştir. Kültürel anlamda ortak bir Türk geleceği, ancak kültürel geçmişin ortaklığını gösteren halk bilimi araştırmalarının üzerine inşa edilebilecektir. Türk halk bilimi uzmanlarının Türk dünyası destanları, masalları, efsaneleri ve fikraları gibi halk edebiyatı türleri hakkında yaptığı bilimsel araştırmalardan elde edilen veriler, tarihî süreç içerisinde birbirinden uzak düşmüş Türk boylarının birbirlerine yakınlaşmasını sağlayacak yol haritasının oluşturulmasında önemli katkılar sağlayacaktır (Gültekin 2010).

Coğrafi genişlik ve tarihî derinlik çerçevesinde kültürel varlığını sürekli bir şekilde devam ettirmiş olan Türk milleti, bugün farklı coğrafyalarda farklı statüde varlığını devam ettirmektedir. Türk topluluklarının yaşadıkları coğrafyayı ifade eden Türk dünyasında Türkler, bugün kendilerine ait bağımsız devletlerin sınırları içerisinde veya başka milletlere bağımlı olarak ya da eski yurtlarında azınlık konumunda bulunmaktadırlar. Günümüzde farklı kıtalara ve ülkelere göç ederek artık oraların vatandaşı olmuş kişilerle diasporada yaşayan Türk topluluklarıyla tarihî süreç içerisinde yakın akrabalık ilişkisi kurarak kültür birlikteliği oluşturduğumuz topluluklar da Türk dünyasının ayrılmaz bir parçadır. Başka bir ifadeyle farklı coğrafyalarda farklı inanç sistemi içerisinde olmakla beraber Türkçenin lehçe ve şivelerini kullanan ve bununla sözlü ve yazılı bir kültür oluşturmuş insanların yaşadıkları bölge bugün Türk dünyası olarak ifade edilmektedir (Yıldırım 1998: 21-22, Yeşil 2014: 17-18). Buran ve Alkaya’ya (2012) göre, Türklerin yaşadığı bu coğrafya 20-90 doğu boylamları ile 33-65 kuzey enlemleri arasında yer almaktadır.

Bugün Türk toplulukları Doğu Avrupadan Çin'in Kuzey Batısına ve Rusyảnın Kuzey Doğusuna kadar olan geniş bir coğrafya içerisine yayılmış bir vaziyette yoğun olarak yaşamaktadırlar. Bugün nüfusu yaklaşık 200 milyon olan Türk Dünyası, dünya nüfusunun \% 3’ünü oluşturmaktadır. Dünyanın birçok bölgesinde yaşayan Türklerin arasındaki ilişki sosyal, siyasal, ekonomik ve kültürel bağlar sayesinde pekişmektedir (Zhamakina 2009). Türk 
toplulukları, ata yurt olarak adlandırılan Orta Asya'nın geniş bozkırlarında bir zamanlar birlikte yaşadıklarının da bir kanıtı olarak günümüzde farklı coğrafyalarda yaşasalar da hâlâ büyük oranda ortak olan bir kültür mirasını taşımaktadırlar. Kültürel miras veya birikimin, genel olarak hayat tarzının da bir sonucu olarak, nesilden nesle ulaştırılması özellikle 20. yüzyılın başlarına kadar sözlü aktarım şeklinde olmuştur. Sözlü ürünler millî kimlik ve millî varlığın korunması mücadelesinde en önemli unsurlardan biri olmuştur. Yazılı ve basılı materyallerin sıkı denetim altında tutulduğu, millî ve dinî kimliği ön plana çıkaracak herhangi bir çalışmanın yapılmasının yasaklandığı bir coğrafyada, denetlenemeyen, kontrol edilemeyen ve baskı altına alınamayan tek unsur sözlü olarak yaratılan ve sözlü olarak anlatılan halk bilgisi ürünleri olmuştur (Gültekin 2010).

Sözlü kültür ürünleri zamanla kendine has birtakım özellikler kazanmış ve bunun neticesinde halkbiliminin bir şubesi olan halk edebiyatının farklı anlatı türleri oluşmuştur. Bu anlatı türlerinin bir kısmı büyük farklılıklara uğrarken bir kısmıssa ortak bir adlandırmayla günümüzde Türk topluluklarının çoğunda yaşamaya devam etmektedir.

Tarihî süreç içerisinde Türk dünyasında, büyük oranda benzer isim ve gelenekle temsil edilen ortak kültürel şahsiyetler ve bu şahsiyetlerin çevresinde gelişen ortak bir Türk dünyası edebiyatından söz etmek mümkündür. Bu edebiyatın ürünlerinin Türk soylu öğrencilere Türkiye Türkçesi öğretiminde araç olarak kullanıldığında kendinden metinlerle karşılaşan öğrencilerin, öğrenmekte oldukları dile yönelik ilgi, tutum ve motivasyonlarını artırması beklenecektedir. Bu noktada, "Türk dünyası edebiyatının hangi ürünleri Türkiye Türkçesi öğretiminde kullanılmalıdır?” sorusunun cevabı önem taşır. Dede Korkut Hikâyeleri, Alpamış Destanı, Köroğlu Destanı, Nasreddin Hoca Fıkraları ve Hoca Ahmet Yesevîye ait şiirler bütün Türk dünyasına mal olmuş edebî kıymetlerdir.

Türk topluluklarında ortak olan en büyük kültürel değerlerin başında, bugün kesin olarak yaşadığı dönem bilinmemekle birlikte farklı bilim adamları tarafından Türklerin İslamiyet'le yeni tanışmaya başladıkları zamanlara kadar geriye götürülebilen Türkiye sahasında Dede Korkut, Türkistan sahasında ise Korkut Ata olarak bilinen tip gelmektedir. Dede Korkut'la ilgili tarihî kaynaklarda kısa ve sınırlı bilgi bulunmaktadır. Bugün onun hakkındaki günümüze ulaşan en hacimli eser Dede Korkut Hikâyeleri olarak bilinen ve 
temelde Dresden (on iki hikâye) ve Vatikan (altı hikâye) olmak üzere iki ana nüshası bulunan bir eserdir. Eserin dil özelliklerine bakılarak 15. yüzyılın sonlarında yazıya geçirildiği düşünülmektedir (Ergin 1997: 23-70). Dede Korkut'la ilgili olarak Türkistan sahasında ise eski tarihli bir yazılı kaynak bulunmayıp onunla ilgili bilgiler halk arasında efsane şeklinde yaşayarak günümüze kadar ulaşmıştır.

Türk dünyasında isim ve içerik olarak benzer olan ortak kültürel değerlerden birisi de Alpamış Destanıdır. Destan, Altaylarda Alıp Manaş, Başkurtlarda Alpamışa, Tatarlarda Alıp Memşen, Kazaklarda Alpamıs, Özbeklerde Alpamış adıyla bilinir ve Anadolu sahasında ise Dede Korkut Hikâyelerinde yer alan "Kam Püre Oğlu Bamsı Beyrek" anlatısıyla benzerlik gösterir. Destan Türk boylarının hayat tarzları ve kültürel etkileşimlerine göre bazı değişikliklere uğramakla beraber günümüzde ortak bir değer olarak varlığını devam ettirmektedir (Jirmunskiy 2011:121-237).

Türk dünyasında ortak isim ve gelenek etrafinda bugün icra edilen eserlerden birisi de Köroğlu’dur. Köroğlu Türk dünyasında genel olarak destan şeklinde icra edilirken Anadolu sahasında bir halk hikâyesi şeklinde icra edilmektedir. Destan Türk boylarının büyük bir çoğunluğuyla beraber Türklere komşu olarak yaşayan Tacik, Gürcü, Ermeni vb. topluluklarda da yaygındır. Bulgaristan'dan Doğu Türkistan'a kadar olan geniş bir coğrafyaya yayılmış olmasının doğal bir sonucu olarak destanın versiyonları arasında büyük farklılıklar bulunmaktadır. Temelde Doğu (Türkmen, Kazak, Özbek, Uygur vb.) ve Batı (Azerbaycan ve Türkiye) olmak üzere iki ana versiyona ayırılabilen destanın Doğu varyantları daha mitolojik olurken Batı varyantlarında büyük ölçüde mitolojik motifler kaybolmuş ve anlatı hikâye şekline dönüşmüştür (Karadavut 2002: 1, Taşlıova 2016: 1-16).

Türk kültüründe ortak olan bazı kültürel değerler sözlü kültürün tabiatına uygun olarak sadece Türk dünyasıyla sınılı kalmayarak tarihî süreç içerisinde Türklerle birlikte yaşamış ve bir dönem Türk kültür coğrafyasının sınırları içerisinde kalmış topluluklara da geçmiştir. Bunun en güzel örneği hiç şüphesiz dünyanın en ön meşhur mizah tiplerinden biri olan Nasreddin Hoca'dır. Nasreddin Hoca'nın 13. yüzyılda Anadolu sahasında yaşamış tarihî bir şahsiyet olduğu büyük ölçüde kabul görmüş olmakla beraber o, bir fikra ve efsane tipi olarak bugün Türk dünyası ve tarihî Türk kültür coğrafyasında hâlâ canlı bir şekilde varlığını devam ettirmektedir. Nasreddin hoca bugün Türk dünya- 
sında Sibirya Türkleriyle Sarı Uygurlar dışında kalan topluluklarda bir mizah tipi olarak bilinmekte, Türk dünyasında Nasretdin Huca, Nasredin Afandi, Nesreddin Ependi, Kojanasır, Koco Nasirdin, Molla Nasraddin, Nasra Hoca vb. isimlerle yaşamaktadır. Ünü sadece Türk ve Müslüman olan topluluklarla sınırlı kalmayan Nasreddin Hoca; Bulgar, Makedon, Hırvat, Sırp, Romen ve Macarlar arasına da Osmanlı Devleti zamanında yayılmış ve Bulgarlarda Hıtar Petar, Makedonlarda Itar Peyo gibi hayalî tiplerin oluşmasına ilham vermiştir (Özkan 1999: 17-22).

Türk dünyasının bugün ortak en büyük değerlerinden birisi hiç şüphesiz 11 ve 12. yüzyıllarda yaşamış olan Ahmet Yesevîdir. İslamiyet' in Orta Asya sahasında yaylak-kışlak hayatı yaşayan Türkler arasında yayılmasında en büyük etkenlerden birisi Türkistan sahasında Pir-i Türkistan, Pir-i Sani, Ahmet-i Sani, Yasavi gibi isimlerle anılan ve bir Türk mutasavvıfı olan Ahmet Yesevî aracılığıyla olmuştur. Ahmet Yesevî İslam'ı, daha çok bulunduğu coğrafyanın insan tipolojisini göz önünde bulundurarak, Arapça ve Farsça bilmesine rağmen, hikmet olarak anılan Türkçe şiirleri aracılığıyla yaymıştır. Ahmet Yesevî ve onun tasavvufi geleneği olan Yesevîlik kendinden sonra Nakşibendilik ve Bektaşilik gibi iki büyük düşünce sisteminin oluşup gelişmesinde etkili olarak her iki düşünce sisteminde de günümüzde bile hâlâ etkisi devam eden bir yere sahip olmuştur (Köprülü 2003: 85-106).

Türk dünyasından gelen öğrencilerin aynı zamanda kendileri için de önemli olan bu metinleri ders kitaplarında, yardımcı okuma kaynaklarında veya öğretmenlerin hazırladığı etkinliklerde görmesi, öğrenecekleri dile karşı yabancilık hissetmemelerine ve en önemlisi, gerçekten öğrenmek istemelerine katkı sağlayacaktır. Öğrenme, öğrencilerin bir şeyi öğrenmek istemeleriyle gerçekleşen bir süreçtir. Türkiye Türkçesi öğreticilerinin de öğrencinin derse karşı olumlu tutum sahibi olmasını sağlayacak davranışları/etkinlikleri bilmesi ve bu davranışları/etkinlikleri ders öncesinde ve sırasında kullanması gerekir (Acat ve Demiral 2002: 314). Bu bakımdan yapılması gereken öncelikli işlerden biri, Türkiye Türkçesi metinlerine yönelik öğrenci tutumlarının belirlenmesidir.

Bugüne kadar ikinci dil öğrenmeye yönelik okuma tutumları pek çok yönden araştırmalara konu edilmiştir. Okuma tutumu çalışmalarının, öğrenenlerin doğrudan ikinci dilde okudukları metinlerle (Ghazali 2009) ilgili olduğu gibi, e-kitap okumaları (Chen vd. 2013, Lin 2010), tutumların ana dilden 
ikinci dile aktarımı (Yamashita 2004, 2011), okunan metinlerin sıklı̆̆ının tutumlara etkisi (Crawford Camiciottoli 2001) ve akademik olmayan metinler (Ro ve Chen 2014) vb. alanlarda da yapıldığı görülmektedir. Literatür incelendiğinde Türkçenin gerek yabancilara gerekse Türk soylulara öğretimi alanında okunan metinler veya Türkçe okumaya yönelik okuma tutumu araştırmalarının olmadığı görülmektedir.

\section{Araştırmanın Amacı}

Araştırmanın temel amacı, Türk dünyasından çeşitli sebeplerle gelerek ülkemizde bulunan ve Türkiye Türkçesi öğrenimlerine devam eden Türk soylu öğrencilerin Türkiye Türkçesi ile hazırlanan metinlere yönelik tutumlarını belirlemektir.

\section{Yöntem}

Belirlenen amaca ulaşmak için nitel ve nicel veriler birlikte kullanılmıştır. Nitel veriler belirli bir çalışma grubunun özelliklerini derinlikli olarak yansıtırken nicel araştırma metotlarının kullanılması araştırmanın sonucunda nicel, genellenebilir; ama derinlikli olmayan bir sonuç ortaya koyar. Bu durum göz önüne alınarak araştırma evreninin tutumlarına ait kategorileri derinlikli olarak incelemek ve evrene genellenebilir verileri ortaya koymak amacıyla araştırmanın karma yöntem ile tasarlanmasına karar verilmiştir (Creswell 2017, Creswell 2003, Lisle 2011, Morse 2003, Creswell 2012, Creswell and Clark 2011, Özden and Durdu 2016, Punch 2016.).

Araştırma amacına bağlı olarak karma yöntem araştırmalarından keşfedici siral desen tercih edilmiştir. Desenden hareketle önce belirli ve homojen çalışma grupları ile odak grup görüşmelerinin yapılması, sonrasında oluşan tema ve kategorilerin evreni oluşturan katılımcılarca ne ölçüde paylaşıldığının belirlenmesi hedeflenmiştir. Bu yolla nitel araştırma sürecinin üzerine bina edilen nicel bir yapı oluşturulmuştur (Creswell 2003: 211, Creswell and Clark 2015: 94).

İlk aşama durum çalışması deseninde bütüncül tek durum deseni ile tasarlanmıştır. Türk soyluların Türkiye Türkçesi ile oluşturulmuş metinleri okumaya yönelik tutumları ilgili durumun ana çerçevesini oluşturduğu için bütüncül tek durum deseni tercih edilmiştir. Öğrencilerin yan yana yaptıkları beyin fırtınalarında daha derinlikli veri ortaya koyacakları düşünülerek odak grup görüşmesi metodunun kullanılmasına karar verilmiştir (Yıldırım ve 
Şimşek 2016, Yin 2011). Bu sayede nitel araştırma grubunu oluşturan katılımcıların Türkiye Türkçesinde oluşturulmuş metinleri okumaya yönelik tutumlarının belirlenmesine yönelik nitel bulgularla derinlikli veri elde edilmesi sağlanmış, nicel boyutta ise elde edilen sonuçların araştırma evrenine genellenebilir olup olmadığı belirlenmiştir.

\section{Çalışma Grubu, Evren ve Örneklem}

Araştırmanın nitel verileri nitel örnekleme metotlarından homojen örnekleme ile oluşturulmuş; Yıldız Teknik Üniversitesi TÖMER'den 4, İstanbul Aydın Üniversitesi TÖMER'den 8 öğrenci ile odak grup görüşmesi yapılmıştır. Öğrencilerin Türk soylu olması odak grup görüşmesi yapılan grubun homojen olmasını sağlarken Türkçe iletişim becerilerinin odak grup görüşmesi için fiilen B1-B2 seviyesinde olması esas alınmıştır.

Nicel verilerin toplanmasında araştırma amacına bağlı olarak amaçsal örnekleme yöntemlerinden ölçüt örnekleme seçilmiştir. Gözlem birimlerinin belli niteliklere sahip kişiler, olaylar, nesneler ya da durumlar olduğu durumlarda örneklem için belirlenen ölçütü karşılayan birimler araştırmada örneklemi oluştururlar (Büyüköztürk, Kılıç Çakmak, Erkan Akgün, Karadeniz \& Demirel 2017: 94-95). Araştırmanın gözlem birimini Türk soylu öğrenciler oluşturduğu için örneklem seçiminde ölçüt öğrencilerin kendisini Türk olarak tanımlaması kabul edilmiştir. Bu bağlamda evreni Türkiye’deki üniversitelerin Türkçe öğretim merkezlerinde Türkiye Türkçesi öğrenen Türk soylu öğrenciler oluştururken örneklemi Yıldız Teknik Üniversitesi TÖMER, İstanbul Üniversitesi DİLMER, İstanbul Aydın Üniversitesi TÖMER, Sakarya Üniversitesi TÖMER, Erciyes Üniversitesi TÖMER, Akdeniz Üniversitesi TÖMER, Erzincan Üniversitesi TÖMER, Sakarya Üniversitesi TÖMER, Sabahattin Zaim Üniversitesi TÖMER, Gazi Üniversitesi TÖMER, Ankara Yıldırım Beyazıt Üniversitesi DİLMER, Karadeniz Teknik Üniversitesi TÖMER'de öğrenim gören 150 öğrenci oluşturmaktadır.

\section{Veri Toplama Araçları, Verilerin Toplanması ve Analiz Süreci}

Araştırmada evren üzerinde test edilecek veri havuzunu oluşturmak için öncelikle Sallabaş, Göktentürk ve Yazıcı (2018) tarafından geliştirilen "Türkçe Metinlere Yönelik Tutum Ölçeği” nin faktör yapısı incelenmiş, ayrıca literatür incelemesi ile elde edilen veriler raporlaştırılmıştır. Yapılan incelemeler sonucunda nitel aşamada kullanılacak veri toplama aracı olarak yarı yapı- 
landırılmış görüşme formu hazırlanmış, iki Türkçe eğitimi alan uzmanından form hakkında görüş alınmıştır.

Görüşmeler neticesinde elde edilen veriler içerik analizi ile NVivo programında çözümlenmiş ve araştırmacılar tarafindan elde edilen bulguların güvenilir olma derecesi uzman görüşü ile belirlenmiştir. Bu süreçte Miles ve Huberman (1994: 64 ) tarafından geliştirilen şu formülden faydalanılmış ve $\% 70$ üstü başarı şartı aranmıştır:

\section{Güvenilir Olma $=\frac{\text { Görüş Birliğ } i}{\text { Görüş Birliğ } i+\text { Görüş Ayrllı̆̆ }} \times 100$}

Araştırmanın nicel boyutunda Sallabaş, Göktentürk ve Yazıcı (2018) tarafından geliştirilmiş olan “Türkçe Metinlere Yönelik Tutum Ölçeği” kullanılmıştır. Araştırmanın literatür taraması aşamasında Türkçe metinleri okumaya yönelik tutum ölçeğinin faktör yapısının ve faktörlerinin nitel bulgulardan hareketle oluşturulmuş hipotezleri sınamaya yeterli olduğuna karar verilmiş, bu sebeple yeni bir ölçme aracının geliştirilmesine gerek duyulmamıştır. Elde edilen nitel bulgulardan hareketle "Nitel bulgular evrene genellenebilir mi?" problem cümlesine cevap aranmıştır. Nitel bulguların evrene genellenebilir olup olmadığının belirlenmesi için nicel veriler SPSS paket programında çözümlenmiştir. Elde edilen verilerin analizinde betimleyici istatistik (frekans, yüzde ve ortalama), T-testi ve ANOVA analizleri kullanılmıştır. Verilerin karşılaştırılmasında anlamlılık düzeyi .05 olarak kabul edilmiştir.

\section{Araştırmanın Güvenirliği}

Araştırmadan elde edilen nitel verilerin NVivo'da çözülmesi sonrasında elde edilen temaların güvenilir olma derecesinin belirlenmesi için 1 alan uzmanına temalar ve alt kategoriler sunulmuştur. Uzmana sunulan 8 temadan 7’i kabul görmüş 1 'ine ise düzeltme verilmiştir. Bu sonuçla temaların $\% 87,5$ oranında güvenilir olduğu sonucuna ulaşılmıştır. 46 adet alt kategorinin ise 38'i kabul görmüş, kalan 7 başlık içinse ret verilmiştir. Elde edilen sonuçlar Miles ve Huberman'ın (1994: 64 ) güvenilir olma formülüne göre analiz edilmiştir.

\section{Araştırmanın Hipotezleri}

Araştırmanın nitel bulgularından hareketle hipotezleri şu şekilde oluşturulmuştur: 
1. Türkiye Türkçesi öğrenen Türk soylu öğrencilerin Türkçe metinlere yönelik etkinlikte bulunmaya dair tutumu olumludur.

2. Türkiye Türkçesi öğrenen Türk soylu öğrencilerin Türkçe metinlere yönelik duyguları olumludur.

3. Türkiye Türkçesi öğrenen Türk soylu öğrencilerin Türkçe metinlerin ehemmiyetini fark etmeye yönelik tutumları olumludur.

4. Türkiye Türkçesi öğrenen Türk soylu öğrencilerin Türkçe metinlerdeki kültür unsurlarına yönelik tutumları olumludur.

\section{Bulgu ve Yorumlar}

\section{Nitel Bulgular}

Araştırmanın nitel boyutunda Yıldız TÖMER'den 4, İstanbul Aydın Üniversitesi TÖMER'den 8 öğrenci ile odak grup görüşmesi gerçekleştirilmiştir. Yapılan görüşmeler öğrencilerin rızası doğrultusunda ses kaydına alınmıştır. Kayıtlar tek bir veri havuzu hâline dönüştürülerek NVivo programında analiz edilmiş ve şu temaların oluştuğu görülmüştür:

\begin{tabular}{|c|c|}
\hline Temalar & İçerik \\
\hline 1. Hayata Uygunluk & $\begin{array}{l}\text { Yabancı dil olarak Türkçe ders kitaplarındaki me- } \\
\text { tinlerin hayata uygunluğuna dair katılımcı görüş- } \\
\text { lerini içeren kategorilerden oluşmaktadır. }\end{array}$ \\
\hline 2. Kültür Aktarımı & $\begin{array}{l}\text { Yabancı dil olarak Türkçe ders kitaplarındaki me- } \\
\text { tinlerin kültür aktarımı yönüne dair katılımcı gö- } \\
\text { rüşlerini içeren kategorilerden oluşmaktadır. }\end{array}$ \\
\hline 3. Metin Özellikleri & $\begin{array}{l}\text { Yabancı dil olarak Türkçe ders kitaplarındaki me- } \\
\text { tinlerin özelliklerine dair katılımcı görüşlerini içe- } \\
\text { ren kategorilerden oluşmaktadır. }\end{array}$ \\
\hline 4. Tavsiye ve Teklifler & $\begin{array}{l}\text { Yabancı dil olarak Türkçe ders kitaplarındaki me- } \\
\text { tinlere yönelik katılımcıların tavsiye ve tekliflerini } \\
\text { içeren kategorilerden oluşmaktadır. }\end{array}$ \\
\hline 5. Tür & $\begin{array}{l}\text { Yabancı dil olarak Türkçe öğrenen katılımcıların } \\
\text { Türkçe öğrenmeleri hâlinde Türkçe literatürden } \\
\text { okumak istedikleri yazı türleri hakkında görüşle- } \\
\text { rini içeren kategorilerden oluşmaktadır. }\end{array}$ \\
\hline 6. Türk Dünyas1 Kültürü & $\begin{array}{l}\text { Yabancı dil olarak Türkçe ders kitaplarındaki } \\
\text { metinlerde Türk dünyası kültürüne ait unsurların } \\
\text { bulunmasına dair katılımcıların görüşlerini içeren } \\
\text { kategorilerden oluşmaktadır. }\end{array}$ \\
\hline 7. Türkçe Kitaplar Okuma & $\begin{array}{l}\text { Yabancı dil olarak Türkçe öğrenen katılımcıların } \\
\text { Türkçe kitaplar okumaya yönelik görüşlerini içe- } \\
\text { ren kategorilerdir. }\end{array}$ \\
\hline 8. Türkçe Öğrenmeye Katkılar & $\begin{array}{l}\text { Yabancı dil olarak Türkçe ders kitaplarındaki me- } \\
\text { tinler hakkında yabancı dil olarak Türkçe öğrenen } \\
\text { katılımcıların Türkçe öğrenmesine yönelik ilgili } \\
\text { metinlerin katkılarına dair katılımcı görüşlerini } \\
\text { içeren kategorilerdir. }\end{array}$ \\
\hline
\end{tabular}


Nitel bulguların birinci temasını oluşturan "Hayata Uygunluk" teması "Günlük Hayata Uygun Olmama”, "Günlük Hayata Uygunluk” ve "Türk Kültür Unsurlarını Tanıtmada Yetersizlik” kategorilerinden oluşmaktadır. "Günlük Hayata Uygun Olmama” \%2,01 oranına, "Günlük Hayata Uygunluk" \%0,29 oranına, "Türk Kültür Unsurlarını Tanıtmada Yetersizlik” \%2,47 oranına sahiptir. Katılımcılardan elde edilen verilerde "Günlük Hayata Uygunluk" sadece \%0,29 oranına sahipken "Günlük Hayata Uygun Olmama” hususunda ise \%2,01 oranında görüş belirtildiği ve katılımcıların daha ziyade bu yönde görüş taşıdığı görülmektedir. Bununla birlikte katılımcılar Türk kültürünün tanıtılmasında ders kitaplarını yetersiz olarak görmektedir.

"Kültür Aktarımı" teması altında verilen kategorilere bakıldığında "Hedef Dilin Kültürünün Öğretilmesi” \%1,37 oranına, “Türk Kültür Unsurlarını Tanıtma” \%2,47 oranına sahiptir. Elde edilen bulgulardan hareketle katılımcıların ders kitaplarını hedef dilin kültürünün öğrenilmesinde ve Türkiye gözünden Türk kültürünün unsurlarının öğrenilmesinde katkı sağlayacak bir kaynak olarak gördüğ̈ söylenebilecektir.

"Metin Özellikleri” temasındaki "Başlık-Metin Uyumsuzluğu” \%1,16 oranına, "Dinleme Metinlerinin Hızlı Okunması" \% 1,75 oranına, "İlgi Çekicilik" \%5,41 oranına, "Seviyeye Uygunluk" \%3,40 oranına, "Yeterlilik" kategorisi ise \%3,87 oranına sahip görülmektedir. Ortaya kategori ve oranlarından hareketle yabancı dil olarak Türkçe ders kitaplarındaki metinlerde başlık-metin uyumsuzluğunun gözlendiği, A1-A2 seviyelerindeki dinleme metinlerindeki dinleme kayıtlarının okunma hızı sebebiyle öğrencilerin metni takip etmede zorlandığı görülmektedir. Bununla birlikte metinlerin katılımcılar tarafından ilgi çekici, seviyeye uygun ve yeterli görüldüğü tespit edilmiştir.

“Türk Dünyası Kültürü” teması altında yer alan kategorilere bakıldığında “Ortak Türk Kültürü Unsurları" \%7,07 oranına, "Hedef Dilin Şehirlerinin Öğretilmesi” \%1,11 oranına, "Şehirlerde Benzerlikleri Tanıtmanın Faydalılığı” \%0,81 oranına, "Şehirlerde Ortak Kültür Unsurları" \%1,60 oranına sahiptir. Kendi içinde iki alt kategoriye ayrılan "Türk Dünyası Şehirlerinin Tanıtılması" kategorisinde ilgili kategoriye ait genel ifadeler toplam metnin \%3,64’ünü, alt kategorilerinden "Başkentlerin Tanıtılması" \%2,91 oranını, "Ünlü Şehirlerin Tanıtılması” kategorisi ise \% 1,16 oranını almıştır. Elde edilen kategori ve oranlardan hareketle katılımcıların Türk dünyasına ait şehirlerin ders kitaplarında yer almasını ekseriyetle benimsediği, bununla birlikte 
katılımcıların Türkiye'de eğitim alacakları için Türkiye'deki şehirlerin tanıtılmasının öncelikli olması gerektiğine dair görüş belirttiği de tespit edilmiştir.

Katılımcıların Türkçe öğrenme sürecini tamamlamalarının ardından Türkçe metinlerde hangi yazılı anlatım türlerini okuduklarına dair kategorilerin açıklandığı "Tür" temasında "Bilim" kategorisi \%2,62 oranına, "Dilbilim" kategorisi \%0,44 oranına, "Edebiyat" kategorisi \%1,11 oranına sahiptir. Edebiyat kategorisi ise kendi içinde 3 alt kategoriye ayrılmıştır. "Şiir" kategorisi \%0,15 oranına, "Sosyal Bilimler" \%0,61 oranına, "Felsefe" \%0,29 oranına, "Tarih" \%0,73 oranına sahiptir. Katılımcıların Türkçe öğrendikten sonra ilgili başlıklarda Türkçe metinleri okumaya yönelik etkinliklerde bulunacağı ilgili kategoriler yoluyla elde edilen bulgular ışığında söylenebilecektir. Katılımcıların eğitim dönemleri sürerken Türkçe kitaplar okumaya yönelik görüşlerini içeren "Türkçe Kitaplar Okuma” teması dâhilindeki "Türkçe Edebî Metinleri Severek Okuma” kategorisi \%2,71 oranına, "Türkçe Literatürden Faydalanma" kategorisi ise \% 1,66 oranına sahiptir. Elde edilen bulgular katılımcıların Türkiye Türkçesi metinlerini severek okuduğunu ve Türkçe literatürden faydalanma noktasında aktif olarak Türkçe metinleri kullandıklarını göstermektedir.

Katılımcıların yabancı dil olarak Türkçe ders kitaplarındaki metinlerin Türkçe öğrenmeye yönelik katkılarına ait kategoriler "Türkçe Öğrenmeye Katkılar” temasında sunulmuştur. İlgili tema içindeki kategorilere bakıldığında "Basamaklı Gelişim" \%1,02 oranına, "Dilbilgisi ve Dil Becerilerini Geliştirme" \%2,27 oranına, "İletişim Becerisini Geliştirme" \%0,29 oranına, "Kelime Öğretimi” \%0,29 oranına, "Türkçe Öğrenmede Pozitif Katkı" \%1,95 oranına, "Türkçe Öğrenmeyi Kolaylaştırma" \%2,04 oranına, "Yeni Bilgiler Öğrenme" \%0,15 oranına, "Yeni Kelimelerin Öğretimi” \%0,67 oranına sahiptir. Belirtilen bulgular ışı̆̆ında katılımcıların Türkçe ders kitaplarındaki metinler sayesinde katılımcıların basamaklı öğrenmeye uygun bir gelişim gösterdiği, dilbilgisi hususunda bilgilerini geliştirerek dil becerilerini geliştirdiği, iletişim becerilerini geliştirdiği, yeni kelimeler öğrendiği ve Türkçe öğrenmelerinin kolaylaştı̆̆ söylenebilecektir.

Son olarak Öğrencilerin yabancı dil olarak Türkçe ders kitaplarındaki metinlerin daha iyi olması için tavsiye ve tekliflerini içeren "Tavsiye ve Teklifler" temasına bakıldığında "İstenilen Konular" üst kategorisinin altında "Futbol" 
\%0,58 oranına, "Hedef Dile Ait Unsurlar" \%0,58 oranına, "Keşifler ve İcatlar" \%0,73 oranına, "Mesleklere Ait Metinler" \%2,33 oranına, "Sağlık" \%0,38 oranına, "Tarih" \%0,15 oranına, "Teknoloji" 0,20 oranına sahiptir. “Türk Dünyası Ülkeleri” kategorisinin alt kategorilerine bakıldığında "Türk Dünyası Ülkelerinin Benzerlik ve Farklılıkları” \%2,73 oranına, “Türk Dünyasında Misafirlik Âdetleri” \%1,40 oranına, "Ülkelerin Tanıtılması" \%3,03 oranına sahiptir. "Yeni Yerlerin Tanıtılması" \%0,52 oranına sahiptir ve bu kategoriler ders kitaplarında olması istenilen konuları oluşturmaktadır. "İstenilmeyen Konular" kategorisinde ise "Moda" kategorisi \%1,66 oranına sahiptir.

Katılımcıların görüşlerinden hareketle ders kitaplarının öğrencileri Türkçenin konuşulduğu hayat alanlarına hazırlamada, Türkiye'nin kültürel unsurlarının öğrencilere aktarılmasında, Türkçe öğrenmeye katkı sağlamada önemli görevler üstlendiği görüşünün ciddi bir yer tuttuğu görülmüştür.

Ders kitaplarındaki metinlerin özelliklerine bakıldığında "başlık ve metinler arasındaki uyumsuzluk" olumsuz başlıklar olarak ön plana çıkmaktadır. Bununla birlikte metinlerin ilgi çekici, seviyeye uygun ve yeterli olduğu görüşü ağırlık kazanmaktadır.

Türk dünyası kültürü ile ilgili başlıklara bakıldığında katılımcıların Türk dünyası içindeki ortak kültür unsurlarını ders kitaplarında görmek istediği, ayrıca Türk dünyası şehirlerini başkentler ve önemli şehirler başta olmak üzere ders kitaplarında yer almasını istedikleri görülmektedir.

Tavsiye ve teklifler kısmına bakıldığında öğrencilerin kategorilerde belirtilen başlıklara uygun olarak ilgili konulardaki metinleri de ders kitaplarında görmek istedikleri tespit edilmiştir. Elde edilen bulgulardan hareketle katılımcıların Türkiye Türkçesi metinleri okumaya karşı olumlu görüşe sahip olduğu ve ders kitaplarındaki metinlerin Türkçe öğrenmelerini olumlu yönde etkilediği söylenebilir.

\section{Nicel Verilere Yönelik Bulgular}

Bu bölümde Türk dünyasından gelen öğrencilerin Türkçe metinleri okumaya yönelik tutumları nicel veriler doğrultusunda ortaya konulmuş ve yorumlanmıştır. 
Türk soylu öğrencilere uygulanan ölçek 25 maddeden oluşmakta ve 7’li likert tiptedir. Öğrencilerin ölçekten alabilecekleri en çok puan 175, en düşük puan 25 'tir. Yapilan analiz sonucunda öğrencilerin Türkçe metinlere yönelik tutumları şöyledir:

Tablo 1. Türkçe Metinlere Yönelik Tutumlar

\begin{tabular}{lcc}
\hline Tutumlar & F & $\mathbf{\%}$ \\
\hline Orta & 43 & 28,7 \\
\hline Yüksek & 107 & 71,3 \\
\hline Toplam & 150 & 100 \\
\hline
\end{tabular}

Tablo 1'e bakıldığında öğrencilerin tutumlarının orta ve yüksek düzeyde kümelendiği görülmektedir. Buna göre öğrenciler Türkçe metinlere yönelik düşük düzeyde tutum göstermediklerini ifade etmişlerdir. Araştırmaya katılan öğrencilerden 43 'ünün \%28,7 oranla orta düzeyde tutum gösterdiği, 107 'sinin ise $\% 71,3$ oranla yüksek düzeyde tutum gösterdiği belirlenmiştir.

Türk dünyasından gelen öğrencilerin Türkiye Türkçesi metinlere yönelik okuma tutumları çeşitli değişkenler bakımından ele alınmıştır. Bu değişkenlerden cinsiyet, Türkiye’ye gelmeden önce Türkçe eğitimi alma durumu, yazma dersi dışında Türkçe metin yazma ve boş zamanlarda Türk televizyonları izlemeye yönelik yapılan $\mathrm{t}$ testi sonuçlarına yönelik tablo aşağıdadır:

Tablo 2. Türkçe Metin Okumaya Yönelik Tutumlara Dair Değģ̧skenlerin t Testi Sonuçları

\begin{tabular}{lccccccc}
\hline Değişken & Grup & $\mathbf{N}$ & $\bar{X}$ & Ss & T & Sd & P \\
\hline Cinsiyet & Kız & 76 & 138,96 & 21,11 &, 921 & 148 &, 358 \\
& Erkek & 74 & 135,87 & 19,81 & & & \\
\hline Daha Önce Türkçe & Evet & 29 & 138,96 & 3,28 &, 446 & 148 &, 657 \\
Eğitimi Alma & Hayır & 121 & 137,07 & 1,92 & & & \\
\hline Türkçe Öğrenmenin Zor & Evet & 10 & 122,60 & 14,60 & $-2,410$ & 148 &, 017 \\
Olduğunu Düşünme & Hayır & 140 & 138,50 & 20,45 & & & \\
\hline Yazma Dersi Dışında & Evet & 67 & 140,25 & 20,28 & 1,519 & 148 &, 131 \\
Türkçe Metin Yazma & Hayır & 83 & 135,16 & 20,46 & & & \\
\hline Türk Televizyonları & Evet & 119 & 140,49 & 19,41 & 3,734 & 148 &, 000 \\
İleme & Hayır & 31 & 125,70 & 20,51 & & & \\
\hline
\end{tabular}

Tablo 2'ye bakıldığında, Türk soylu öğrencilerin cinsiyet, daha önce Türkçe eğitimi alma, yazma dersi dışında Türkçe metin yazma değişkenlerine göre 
okuma tutum puanlarının anlamlı bir farklılık göstermediği $(>, 05)$ belirlenmiştir. Kız öğrencilerin Türkçe metinleri okumaya yönelik puan ortalamalarının $(138,96)$ erkek öğrencilerin puan ortalamalarına göre $(135,87)$ daha yüksek olduğu; daha önce Türkçe eğitimi alan öğrencilerin puan ortalamalarının $(138,96)$ almayan öğrencilerin puan ortalamalarına $(137,07)$ göre daha yüksek olduğu; yazma dersi dışında Türkçe metin yazan öğrencilerin puan ortalamalarının $(140,25)$ yazmayanların puan ortalamalarına göre $(135,16)$ daha yüksek olduğu belirlenmiştir. Türk soylu öğrencilerin Türkçe öğrenmenin zor olduğunu düşünme ve Türk televizyonlarını izleme değişkenlerine göre okuma tutum puanlarında anlamlı bir farklılık $(<, 05)$ görülmüştür. Buna göre, Türkçenin zor olduğunu düşünenlerin Türkçe metinleri okumaya yönelik okuma tutum puan ortalamalarının $(122,60)$ zor olduğunu düşünmeyenlerin puan ortalamalarından $(140,25)$ daha düşük olduğu; Türk televizyonlarının izleyenlerin puan ortalamalarının $(140,49)$ izlemeyenlerin puan ortalamalarından $(125,70)$ daha yüksek olduğu belirlenmiştir.

Türk soylu öğrencilerin Türkçe metinlere yönelik okuma tutumlarının Türkçe öğrenme amaçlarına göre farklılaşıp farklılaşmadığını belirlemek amacıyla yapılan tek yönlü varyans analizi (ANOVA) sonuçları Tablo 3 ve Tablo 4'te verilmiştir.

Tablo 3. Türk Soylu Öğrencilerin Türkçe Öğrenme Amaçlarna Göre Türkçe Metinlere Yönelik Okuma Tutum Düzeylerini Gösteren ANOVA Testi Sonuçları

\begin{tabular}{lccc}
\hline Türkçe Öğrenme Amacı & $\mathbf{N}$ & $\bar{X}$ & Std. Sapma \\
\hline Ĕğitim & 134 & 138,28 & 19,99 \\
\hline İş & 14 & 131,21 & 24,82 \\
\hline Evlilik & 2 & 124,50 & 17,67 \\
\hline Toplam & 150 & 137,44 & 20,47 \\
\hline
\end{tabular}

Tablo 3 incelendiğinde, en yüksek puan ortalamasının 138,28 ile eğitim görmek için Türkiye Türkçesi öğrenen öğrencilere ait olduğu, bunu sırasıyla 131,21 ortalama ile iş, 124,50 ortalama ile evlilik için Türkiye Türkçesi öğrenenlerin izlediği görülmektedir.

Türk soylu öğrencilerin Türkiye Türkçesi öğrenme amaçlarına göre Türkçe metinlere yönelik okuma tutumu düzeylerinin farklılaşmasına ilişkin varyans analizi sonuçları Tablo 4’te verilmiştir. 
Tablo 4. Türk Soylu Öğrencilerin Türkiye Türkçesi Öğrenme Amaçlarnna Göre Türkçe Metinlere Yönelik Okuma Tutumu Düzeylerinin Farklilaşmasına İlişkin Varyans Analizi Sonuçları

\begin{tabular}{lccccc}
\hline Türkçe Öğrenme Amacı & KT & Sd & KO & F & P \\
\hline Gruplar Arası & 972,879 & 2 & 486,439 & 1,163 &, 315 \\
\hline Grup İçi & 61488,081 & 147 & 418,286 & & \\
\hline Toplam & 62460,960 & 149 & & & \\
\hline
\end{tabular}

Tablo 4 incelendiğinde Türk soylu öğrencilerin Türkçe metinlere yönelik okuma tutumlarında, Türkçe öğrenme amaçlarının anlamlı bir farklılık oluşturmadığ $1(\mathrm{~F}=1,163, \mathrm{p}>, 05)$ belirlenmiştir.

Türk soylu öğrencilerin Türkçe metinlere yönelik okuma tutumlarının Türkiyede yaşadıkları süreye göre farklılaşıp farklılaşmadığını belirlemek amacryla yapılan tek yönlü varyans analizi (ANOVA) sonuçları Tablo 5 ve Tablo 6 'da verilmiştir.

Tablo 5. Türk Soylu Öğrencilerin Türkiye'de Yaşadıkları Süreye Göre Türkçe Metinlere Yönelik Okuma Tutum Düzeylerini Gösteren ANOVA Testi Sonuçlar

\begin{tabular}{lccc}
\hline Türkiye'de Yaşadıkları Süre & $\mathbf{N}$ & $\bar{X}$ & Std. Sapma \\
\hline 0-6 Ay & 98 & 138,16 & 21,47 \\
\hline 6 Ay-1 Y1l & 14 & 134,78 & 17,74 \\
\hline 1-3 Yıl & 32 & 136,09 & 20,26 \\
\hline 3 Y1l ve Üstü & 6 & 139,00 & 11,76 \\
\hline Toplam & 150 & 137,44 & 20,47 \\
\hline
\end{tabular}

Tablo 5 incelendiğinde, en yüksek puan ortalamasının 139,00 ile Türkiyede 3 yıl ve üstü süredir yaşayan öğrencilere ait olduğu, bunu sırasıyla 138,16 ortalama ile 0-6 ay, 136,09 ortalama ile 1-3 y1l, 134,78 ortalama ile 6 ay-1 yıl süreyle Türkiyede yaşayan Türk soylu öğrencilerin izlediği görülmektedir.

Türk soylu öğrencilerin Türkiye'de yaşama süresine göre Türkçe metinlere yönelik okuma tutumu düzeylerinin farklılaşmasına ilişkin varyans analizi sonuçları Tablo 4’te verilmiştir. 
Tablo 6. Türk Soylu Öğrencilerin Türkiye'de Yaşadıkları Süreye Göre Türkşe Metinlere Yönelik Okuma Tutumu Düzeylerinin Farklilaşmasina İlişkin Varyans Analizi Sonuçları

\begin{tabular}{lccccc}
\hline Türkiye'de Yaşadıkları Süre & KT & Sd & KO & F & P \\
\hline Gruplar Arası & 222,496 & 3 & 74,165 &, 174 &, 914 \\
\hline Grup İçi & 62238,464 & 146 & 426,291 & & \\
\hline Toplam & 62460,960 & 149 & & & \\
\hline
\end{tabular}

Tablo 6 incelendiğinde Türk soylu öğrencilerin Türkçe metinlere yönelik okuma tutumlarında, Türkiye'de yaşama sürelerinin anlamlı bir farklılık oluşturmadığı $(F=, 174, p>, 05)$ belirlenmiştir.

Türk soylu öğrencilerin Türkçe metinlere yönelik okuma tutumlarının e-posta yazarken en çok kullandıkları dile göre farklılaşıp farklılaşmadığını belirlemek amacıyla yapılan tek yönlü varyans analizi (ANOVA) sonuçları Tablo 7 ve Tablo 8'de verilmiştir.

Tablo 7. Türk Soylu Ögrrencilerin e-posta Yazarken Kullandıkları Dile Göre Türkçe Metinlere Yönelik Okuma Tutum Düzeylerini Gösteren ANOVA Testi Sonuçları

\begin{tabular}{lccc}
\hline e-posta Yazarken Kullandıkları Dil & N & $\bar{X}$ & Std. Sapma \\
\hline Türkçe & 41 & 139,60 & 21,14 \\
\hline Ana Dili & 67 & 140,46 & 19,52 \\
\hline Diğer Diller & 42 & 130,50 & 20,10 \\
\hline Toplam & 150 & 137,44 & 20,47 \\
\hline
\end{tabular}

Tablo 7 incelendiğinde, en yüksek puan ortalamasının 140,46 ile e-postalarının ana dillerinde yazan Türk soylu öğrencilere ait olduğu, bunu sırasıyla 139,60 ortalama ile Türkçe, 130,50 ortalama ile diğer dillerde e-posta yazan Türk soylu öğrencilerin izlediği görülmektedir.

Türk soylu öğrencilerin Türkiye'de yaşama süresine göre Türkçe metinlere yönelik okuma tutumu düzeylerinin farklılaşmasına ilişkin varyans analizi sonuçları Tablo 8'te verilmiştir. 
Tablo 8. Türk Soylu Öğrencilerin Türkiye'de Yaşadıkları Süreye Göre Türkçe Metinlere Yönelik Okuma Tutumu Düzeylerinin Farklllaşmasina İlişkin Varyans Analizi Sonuçları

\begin{tabular}{lcccccc}
\hline $\begin{array}{l}\text { e-posta Yazarken } \\
\text { Kullandıkları Dil }\end{array}$ & KT & Sd & KO & F & P & $\begin{array}{c}\text { Anlamlı } \\
\text { Fark (LSD) }\end{array}$ \\
\hline Gruplar Arası & 2828,047 & 2 & 1414,024 & 3,486 &, 033 & $2-3$ \\
\hline Grup İçi & 59632,913 & 147 & 405,666 & & & \\
\hline Toplam & 62460,960 & 149 & & & & \\
\hline
\end{tabular}

Tablo 8 incelendiğinde Türk soylu öğrencilerin Türkçe metinlere yönelik okuma tutumlarında, e-posta yazarken kullandıkları dilin anlamlı bir farklılık oluşturduğu $(\mathrm{F}=3,486, \mathrm{p}<, 05)$ belirlenmiştir. Gruplar arasında gözlenen bu farkın kaynağını belirlemek için LSD çoklu karşılaştırma testi yapılmıştır. Analiz sonuçları, e-postalarını ana dillerinde yazan Türk soylu öğrencilerin Türkçe metinlere yönelik okuma tutum düzeylerinin diğer dillerde yazanlara göre anlamlı bir şekilde daha yüksek olduğunu göstermiştir.

\section{Sonuç ve Öneriler}

Türkçe günümüzde yalnızca ana dili değil ikinci dil olarak da öğretilmekte, ikinci dil olarak öğretiminde ise hedef kitleler; yabancılar, Türk soylular ve iki dilliler olarak alt başlıklara ayrılmaktadır. İkinci dil olarak Türkçe öğretiminde hedeflenen kitleler kendine özgü yeterlilikler, metodoloji, materyaller ve ölçme değerlendirme anlayışı gerektirmektedir. Özellikle 1990 ’ $1_{1}$ yıllarda Sovyetler Birliği ve Doğu Bloku’nun dağılmasıyla Türk devlet ve topluluklarının aralarındaki irtibat kuvvetlenmiş, Türk dünyasının çeşitli bölgelerinden öğrenciler Türkiye’ye gelerek burada lisans ve lisansüstü seviyede eğitim almaya başlamışlardır. Günümüzde ise aradaki ticari ve toplumsal ilişkilerin de güçlenmesiyle Türk dünyasından gelenlerin Türkçe öğrenme amaçları da çeşitlenmiştir.

Modern eğitim anlayışına uygun olarak günümüz ikinci dil öğretiminde de ölçme-değerlendirme yaklaşım ve araçlarında değişiklikler meydana gelmiştir. Eğitim öğretim sürecinin başında yapılan ölçümler değer kazanmış, öğrenenleri etkileyen psikolojik faktörlerin dil öğrenmedeki başarıya da doğrudan tesir ettiği görülmektedir. Özellikle tutumlar başarının yordanmasındaki etkisi bakımından uzun zamandır ikinci dil öğretiminde araştırmalara konu edilmektedir (Spolsky 1969, Smith 1971, Elliot 1995). Bu durumda 
Türkçenin Türk soylulara öğretiminde öğrenci tutumlarının araştırılmasının literatüre katkı sağlayacağı düşünülebilir.

Bu çalışmada Türk dünyasından gelen öğrencilerin Türkçe metinlere yönelik okuma tutumları araştırılmıştır. Çalışma nitel ve nicel boyutta tasarlanmış, öncelikle öğrencilerle odak grup görüşmesi gerçekleştirilmiş, ardından Türkiye genelindeki Türkçe öğretim merkezlerinde öğrenim görmekte olan Türk soylu öğrencilere tutum ölçeği uygulanmıştır.

Araştırma nitel boyutta; hayata uygunluk, kültür aktarımı, metin özellikleri, tavsiye ve teklifler, tür, Türk dünyası kültürü, Türkçe kitaplar okuma ve Türkçe öğrenmeye katkılar temalarından oluşmuştur. Bu boyutlar altında çalışmanın nitel bulgularına göre; katılımcılar metinlerin günlük hayata uygun olmadığı yönünde görüş belirtirken diğer taraftan Türk kültürünün tanıtılmasında ders kitaplarını yetersiz olarak görmektedirler. Öğrenciler yine de ders kitaplarındaki metinlerin Türk kültürünü öğrenmelerinde katkısı olduğunu söyleyerek metinleri ilgi çekici, seviyeye uygun ve yeterli gördüklerini belirtmişler ancak bazı metinlerde başlık-metin uyumsuzluğu olduğunu, A1A2 seviyesi dinleme metinlerine ait ses kayıtlarının okunma hızı sebebiyle metinleri takip etmede zorlandıklarını aktarmışlardır. Yapılan görüşmede öğrenciler, metinlerde ortak Türk kültürü unsurlarının bulunması yönünde görüş belirtirlerken Türk dünyasına ait şehirlerin ders kitaplarında yer alması gerektiğini, bununla birlikte Türkiye'de eğitim alacakları için Türkiye'deki şehirlerin tanıtılmasının öncelikli olmasını istemişlerdir. Görüşmeye katılan öğrenciler bilimsel metinleri okumaya daha çok ilgi duymakta, Türkiye Türkçesi metinlerini severek okumaktadırlar. Diğer taraftan okudukları metinler Türkçe öğrenmelerine kolaylaştırıcı etki yaparken öğrenciler Türk dünyasını çeşitli yönlerden tanıtıcı metinlerin okudukları metinler arasında yer bulmasını istemektedirler. Yapılan görüşmelerde Türk dünyasından gelen öğrencilerin Türkçe metinler hakkında olumlu görüşe sahip oldukları ve metinleri okumaya istekli oldukları belirlenmiştir.

Çalışmanın nicel boyutunda elde edilen veriler, öğrencilerin Türkçe metinlere yönelik tutum düzeylerinin yüksek olduğunu göstermektedir. Bu bulgu nitel görüşme verilerini desteklemektedir. Araştırmanın nicel boyutunda öğrencilerin tutum puan ortalamalarının çeşitli değişkenlere göre farklılaşıp farklılaşmadığı da ortaya konulmuştur. Buna göre Türk soylu öğrencilerin cinsiyet, daha önce Türkçe eğitimi alma, yazma dersi dışında Türkçe metin yazma 
değişkenlerine göre okuma tutum puanlarının anlamlı bir farklılık göstermediği; Türkçe öğrenmenin zor olduğunu düşünme ve Türk televizyonlarını izleme değişkenlerine göre okuma tutum puanlarında anlamlı bir farklılık görüldüğü belirlenmiştir. Ancak kız öğrencilerin Türkçe metinleri okumaya yönelik puan ortalamalarının erkek öğrencilerin puan ortalamalarına göre daha yüksek olduğu belirlenmiştir. Yapılan pek çok araştırmanın (Sallabaş 2008, Parker ve Paradis 1986, Worrell vd. 2007, Balcı vd. 2012) sonucu da kız öğrencilerin okuma tutum puanlarının erkek öğrencilerin puanlarından yüksek olduğunu göstermektedir. Yine daha önce Türkçe eğitimi alan öğrencilerin puan ortalamalarının almayan öğrencilerin puan ortalamalarına göre daha yüksek olduğu; yazma dersi dışında Türkçe metin yazan öğrencilerin puan ortalamalarının yazmayanların puan ortalamalarına göre daha yüksek olduğu belirlenmiştir. Bu durum, daha önce Türkiye Türkçesi eğitimi almanın Türkçeye karşı bir aşinalık sağladığı ve bu durumun tutum puanlarına yansıdığı şeklinde yorumlanabilir. Diğer taraftan Türkçe öğrenmenin zor olmadığını düşünen öğrencilerin tutum puanları anlamlı bir şekilde yüksek çıkmıştır. Öğrenciler zor olmadığını düşündüklerinde bu durum çoğunlukla duyuşsal eğilimi ifade eden tutumları da etkilemiştir. Arslan ve Adem'e (2010) göre, yabancı dil öğretiminde görsel ve işitsel araçların kullanılması, aktif duyu organlarının etkinliğini artırmakta dolayısı ile öğrenimi kolaylaştırmakta ve hızlandırmaktadır. Çalışmada görsel ve işitsel aynı zamanda eğlenceli bir araç olan Türk televizyonlarını izleyen öğrencilerin puan ortalamalarının izlemeyenlerin puan ortalamalarından anlamlı bir şekilde daha yüksek olduğu görülmüştür. Araştırma bulguları Türk dünyasından öğrencilerin eğitim, iş ve evlilik sebebiyle geldikleri ve Türkiye'de kaldıkları sürelerin farklılaşıı̆ı ancak bu durumların Türkçe metinlere yönelik tutumları üzerinde etkili olmadığı belirlenmiştir. Diğer taraftan e-postalarını ana dillerinde yazan öğrencilerin tutumlarının bildikleri bir başka dilde yazmaya göre anlamlı bir şekilde farklılaştığı, e-postalarını Türkçe yazanların tutum düzeylerinin de yüksek olduğu görülmektedir.

Türk soylular günümüzde Türkçe öğretimindeki başlıca hedef kitlelerden biri durumundadır ancak bu alana özgü yeterli düzeyde öğretimsel bir içeriğin oluştuğunu söylemek oldukça güçtür. Türk soylulara Türkçe öğretiminde verim elde etmek için bu maksatla yazılan kitapların biçim ve içerik yönünden niteliği üzerinde durulmalıdır. Yabancılara Türkçe öğretimi alnında yazılan ders ve yardımcı kitapların hemen hiçbirinde bu husus dikkate alınmamış- 
tır. Türkçe bilmeyenlere Türkçe öğretmek maksadıyla yazılan kitapların içerik ve yöntem bakımından iyi irdelenerek hedef kitlenin hazır bulunuşluk düzeylerine göre düzenlenmesi gerekmektedir (Taştekin 2015). Özellikle başlangıç seviyesinde, Türk soylularla yabancı öğrenciler arasında belirgin bir seviye farkı olduğu göz önünde tutulmalıdır.

Yapılan araştırmanın sonucu dikkate alındığında, Türk soylulara Türkçe öğretimini merkeze alarak ortak kültürel unsurların, Türk dünyasından başlıca mekânlarının tanıtıldığı ve ortak halk edebiyatı ürünlerinin yer aldığı öğretim setleri ve yardımcı okuma kaynaklarının oluşturulması gerekliliği ortaya çıkmaktadır. Var olanların yanı sıra Türk dünyasına özgü içeriğin de sunulduğu öğretim materyallerinin öğrencilerin Türkiye Türkçesi öğrenmelerinde motivasyonlarının artırmasına ve olumlu tutum geliştirmelerine katkı sağlayacağı düşünülebilir.

\section{Kaynaklar}

Acat, Bahattin ve Seyfettin Demiral (2002). “Türkiye'de Yabancı Dil Öğreniminde Motivasyon Kaynakları ve Sorunları”. Kuram ve Uygulamada Eğitim Yönetimi 31: 312-32.

Arslan, Mustafa ve Ergin Adem (2010). "Yabancılara Türkçe Öğretiminde Görsel ve İşitsel Araçların Etkin Kullanımı”. Dil Dergisi 147: 63-86.

Balcı, Ahmet vd. (2012). "İlköğretim 6. Sınıf Öğrencilerinin Okuma Alışkanlıkları, Kütüphane Kullanma Sıklıkları ve Okumaya Yönelik Tutumlarının İncelenmesi”. Turkish Studies 7 (4): 965-985.

Baştuğ, Muhammet ve Hasan Kağan Keskin (2013). "Ergenlik Dönemi Okuma Tutumu Ölçeği'nin Türkçeye Uyarlanması”. Turkish Studies - International Periodical For The Languages, Literature and History of Turkish or Turkic 8 (4): 295-311.

Büyüköztürk, Şener vd. (2017). Bilimsel Araştırma Yöntemleri. Ankara: Pegem Akademi Yay.

Chen, Chin-Neng vd. (2013). "The Effects of Extensive Reading Via E-Books on Tertiary Level EFL Students' Reading Attitude, Reading Comprehension And Vocabulary". The Turkish Online Journal of Educational Technology 12 (2): 303-312.

Crawford Camiciottoli, Belinda (2001). "Extensive Reading in English: Habits and Attitudes of a Group of Italian University EFL Students". Journal of Research in Reading 24 (2): 135-153.

Creswell, John W. (2009). Research Design Qualitative, Quantitative and Mixed Methods Approaches (Third Edition). Thousand Oaks, California: SAGE Publications, Inc.

Creswell, John W. (2012). Educational Research Planning, Conducting, and Evaluating Quantitative and Qualitative Research (Fourth Edition). Boston: Pearson Education, Inc. 
Creswell, John W. (2017). Karma Yöntem Araştırmalarına Giriş. Çev. S. Çelik vd. Ankara: Pegem Akademi Yay.

Creswell, John W. ve Vicki L. Plano Clark (2015). Karma Yöntem Araştırmalarının Tasarımı ve Yürütülmesi. Çev. Yüksel Dede ve Selçuk Beşir Demir. Ankara: Anı Yay.

De Lisle, Jerome (2011). "The Benefits and Challenges of Mixing Methods and Methodologies: Lessons Learnt From Implementing Qualitatively Led Mixed Methods Research Designs in Trinidad and Tobago". Caribbean Curriculum 18: 87-120.

Elliot, A. Raymond (1995). "Foreign Language Phonology: Field Independence, Attitude, and the Success of Formal Instruction in Spanish Pronunciation". The Modern Language Journal 79 (4): 530-542.

Ergin, Muharrem (1997). Dede Korkut Kitabı-I. Ankara: TDK Yay.

Ghazali, Siti Norliana et al. (2009). "ESL Students' Attitude towards Texts and Teaching Methods Used in Literature Classes". English Language Teaching 2 (4): 51-56.

Gültekin, Mustafa (2010). Tataristan Masalları Üzerinde Bir Araştırma. Doktora Tezi. İzmir: Ege Üniversitesi.

İnceoğlu, M. (2000). Tutum-Algı İletişim. Ankara: İmaj Yay.

Jirmunskiy, V. M. (2011). Türk Kahramanlık Destanları. Çev. Mehmet İsmail ve Hülya Arslan Erol. Ankara: TDK Yay.

Kağıtçıbaşı, Çiğdem (1985). İnsan ve İnsanlar. İstanbul: Beta Yay.

Karadavut, Zekeriya (2002). Köroğlu’nun Ortaya Çıkışı. Bişkek: Kırgızistan-Türkiye Manas Üniversitesi Yay.

Karasu, Mehmet (2013). Diyaloğa Dayalı Öğretim Stratejilerinin Okuma Tutum ve Becerilerini Geliştirmeye Etkisi. Doktora Tezi. Ankara: Gazi Üniversitesi.

Karatay, Halit ve Nurettin Kartallığlu (2016). "Yabancı Dil Olarak Türkçe Öğrenme Tutumu ile Dil Becerileri Edimi Arasındaki İlişki”. AİBÜ Sosyal Bilimler Enstitüsü Dergisi 16 (4): 203-213.

Köprülü, Fuat (2003). Türk Edebiyatında İlk Mutasavvıflar. Ankara: Akçağ Yay.

Lin, Chih-Cheng (2010). “"E-Book Flood” for Changing EFL Learners' Reading Attitudes". US-China Education Review 7 (11): 36-43.

Miles, Matthew ve Michael A. Huberman (1994). Qualitative Data Analysis: An Expanded Sourcebook. California: Sage Publications.

Morse, Janice M. (2003). Principles of Mixed Methods and Multimethod Research Design. Ed. Abbas Tashakkori ve Charles Teddle. California: SAGE Publications, Inc.

Özden, M. Yaşar ve Levent Durdu (2016). Eğitimde Üretim Tabanlı Çalışmalar İçin Nitel Araștırma Yöntemleri. Ankara: Anı Yay.

Özkan, İsa (1999). Türkiye ve Tatar Türkçesiyle Nasrettin Hoca Fıkraları. Ankara: Tika Yay.

Parker Anita ve Edward Paradis (1986). "Attitude Development Toward Reading in Grades One Through Six”. Journal of Educational Research 79: 313-315.

Punch, Keith F. (2016). Sosyal Araştırmalara Giriş Nitel ve Nicel Yaklaşımlar. Çev. Zeynep Akyüz vd. Ankara: Siyasal Kitabevi.

Ro, Eunseok ve Cheng-Ling Alice (2014). "Pleasure Reading Behavior and Attitude 
of Non-Academic ESL Students: A Replication Study”. Reading in a Foreign Language 26 (1): 49-72.

Sainsbury, Marian ve Rebecca Clarkson (2008). Attitudes to Reading at Ages Nine and Eleven: Full Report. Slough: NFER.

Sallabaş, Muhammed Eyyüp (2008). "Relationship between 8th Grade Secondary School Students' Reading Attitudes and Reading Comprehension Skills". Inönü University Journal of the Faculty of Education 9 (16): 141-155.

Sallabaş, Muhammed Eyyüp vd. (2018). “Türkçe Metinleri Okumaya Karşı Yabancı Dil Olarak Türkçe Öğrenen Öğrencilerin Tutumunun Belirlenmesi: Bir Geçerlilik ve Güvenilirlik Çalışması”. Ana Dili Ĕ̆itimi Dergisi 6 (2): 369385.

Smith, Alfred N. (1971). "The Importance of Attitude in Foreign Language Learning”. The Modern Language Journal 55 (2): 82-88.

Spolsky, Bernard (1969). "Attitudinal Aspects of Second Language Learning". Language Learning 19 (3-4): 271-286.

Taşlıva, Mete (2016) Köroğlu Oltu Kolu. Ankara: Akçağ Yay.

Taştekin, Ali (2015). “Türk Dillilere Türkiye Türkçesi Ögretimi Nasıl Olmalıdır”. International Journal of Languages' Education and Teaching 3 (3): 43-55.

Ünal, Emre ve Kamil İşeri (2012). "Analysis of the Relationship between Reading and Writing Attitudes of Teacher Candidates and Their Academic Achievements through the Structural Equation Model”. Elementary Education Online 11 (4): 1066-1076.

Worrell, Frank C. vd. (2007). "Elementary Reading Attitude Survey (ERAS) Scores in Academically Talented Students". Roeper Review 29 (2):119-124.

Yamashita, Junko (2004). "Reading Attitudes in L1 and L2, and Their Influence on L2 Extensive Reading”. Reading in a Foreign Language 16 (1): 1-19.

Yamashita, Junko (2007). "The Relationship of Reading Attitudes Between L1 And L2: An Investigation of Adult EFL Learners in Japan”. TESOL Quarterly 41 (1): 81-105.

Yeşil, Yılmaz (2014). Türk Dünyasında Geçiş Dönemi Ritüelleri. Eskişehir: 2013 Türk Dünyası Kültür Başkenti Yay.

Yıldırım, Ali ve Hasan Şimşek (2016). Sosyal Bilimlerde Nitel Araştırma Yöntemleri. Ankara: Seçkin Yay.

Yıldırım, Dursun (1998). Türk Bitiğgi. Ankara: Akçağ Yay.

Yin, Robert K. (2011). Qualitative Research From Start to Finish. New York: The Guilford Press.

Zhamakina, Alfiya (2009). Kazak Masalları Üzerine Bir Inceleme. Yüksek Lisans Tezi. İzmir: Ege Üniversitesi. 


\title{
The Attitudes of The Students Coming From The Turkic World Towards The Texts in Turkey Turkish Language*
}

Fahri Temizyürek $^{* *}$ Muhammed Eyyüp Sallabaş ${ }^{* * *}$

\begin{abstract}
The students called "Foreigners of Turkish Origin" coming from the Turkic world learn Turkey Turkish by travelling to Turkey for several reasons such as work, education, marriage etc. In the teaching process of Turkish, the texts are used both in coursebooks or reading books as the main element of teaching. Thanks to the common values and products put forward by the Turkic world in historical process that the students from the Turkic world are expected to develop a positive interest and attitude to Turkey Turkish. An attitude which is described as a tendency of giving a reaction to an object or a situation is one of the most important elements of education. The success in learning a foreign language of the students who develop a positive attitude to the foreign language they learn or to reading as an ability of that language is expected to be affected by this attitude. In this study in which it was benefited from the mixed method, the attitudes of the students coming from the Turkic world towards Turkish texts were searched. In the research, it was detected that they had developed a high-level attitude towards Turkish texts and expected to see the common cultural elements of the Turkic world among the texts.
\end{abstract}

Keywords

Turkic world, Turkey Turkish, Foreigners of Turkish origin, Turkish teaching, attitude, Reading attitude.

\footnotetext{
Date of Arrival: 05 March 2019 - Date of Acceptance: 17 April 2019

You can refer to this article as follows:

Temizyürek, Fahri and Muhammed Eyyüp Sallabaş (2020). “The Attitudes of The Students Coming From The Turkic World Towards The Texts in Turkey Turkish Language ”. bilig-Journal of Social Sciences of the Turkic World 95: 1-26.

"* Prof. Dr., Gazi University, Faculty of Education, Department of Turkish Language Education - Ankara/ Turkey

ORCID ID: 0000-0002-0497-1045

fahri@gazi.edu.tr

${ }^{* * *}$ Prof. Dr., Yildız Technical University, Faculty of Education, Department of Social Science and Turkish Language Education - İstanbul/Turkey

ORCID ID: 0000-0003-4346-4385

sallabas@yildiz.edu.tr
} 


\title{
Отношение студентов тюркоязычных стран к текстам на турецком языке*
}

\author{
Фахри Темизйюрек* \\ Мухаммед Эюп Саллабаш ${ }^{* * *}$
}

\begin{abstract}
Аннотация
Студенты из тюркоязычных стран и стран так называемого тюркского мира, приезжая в Турцию на учебу, работу и по семейным обстоятельствам, изучают турецкий язык. Базовыми элементами при изучении языка являются соответствующие тексты на турецком языке в учебниках и хрестоматиях. Ожидается, что благодаря использованию текстов из литературного наследия и общей истории тюркского мира у студентов из тюркоязычных стран сформируется положительная реакция и особый интерес к турецкому языку. Именно отношение, будучи реакцией на определенный предмет, объект или ситуацию, является главным элементом при изучении иностранного языка. Это отношение должно положительно повлиять и развить интерес к дальнейшему изучению турецкого языка. В данном исследовании, на основе смешанных методов было изучено отношение студентов из тюркоязычных стран к текстам на турецком языке. В результате было выявлено наличие у студентов высокой мотивации к этим текстам, среди которых они ожидают увидеть фрагменты общего культурного наследия тюркского мира.
\end{abstract}

\section{Ключевые слова}

тюркский мир, турецкий язык, тюркоязычные страны, изучение турецкого языка, реакция, отношение к чтению.

\footnotetext{
П Поступило в редакцию: 05 марта 2019 г. - Принято в номер: 17 апреля 2019 г.

Ссылка на статью:

Temizyürek, Fahri \& Muhammed Eyyüp Sallabaş (2020). “Türk Dünyasından Gelen Öğrencilerin Türkiye Türkçesi Metinlerine Yönelik Tutumları”. bilig - Журнал Гуманитарных Наук Тюркского Mupa 95: 1-26.

** Проф., д-р, Университет Гази, педагогический факультет, кафедра турецкого языка - Анкара / Турция

ORCID ID: 0000-0002-0497-1045

fahri@gazi.edu.tr

*** Проф., д-р, Технический университет Йылдыз, педагогический факультет, отделение общественных наук и турецкого языка - Стамбул / Турция

ORCID ID: 0000-0003-4346-4385

sallabas@yildiz.edu.tr
} 